\title{
Manajemen Pengetahuan Sebagai Variabel Pemoderasi, Pengaruh Budaya Organisasi dan Iklim Organisasi Terhadap Kompetensi
}

\author{
Dewi Cahyani Pangestuti ${ }^{1^{*}}$, Renny Husniaty ${ }^{2^{*}}$ \\ * Universitas Pembangunan Nasional Veteran Jakarta \\ Fakultasl Ekonomil danl Bisnisl Programl Studil Manajemen \\ JL. RS. Fatmawati No. 1, Pondok Labu, Jakarta Selatan 12450, Indonesia \\ E-mail: dewichepe@upnvj.ac.id \\ E-mail: renyhusniati@gmail.com
}

\begin{abstract}
Abstrak
Penelitian bertujuan untuk mengkaji pengaruh Budaya Organisasi, Iklim Organisasi, Manajemen Pengetahuan dan Kompetensi Pegawai secara langsung maupun tidak langsung. Adapun populasi dalam penelitian ialah pegawai KPP Pratama Jakarta Tanjung Pluit yang tersebar dalam 11 seksi yaitu seksi Umum, Pelayanan, PDI, Ekstensifikasi, Pemeriksaan, Penagihan, Pengawasan dan Kosultasi 1 - 4, dan Fungsional Pemeriksa sebesar 107 orang Pegawai Negeri Sipil yang bertugas di KPP Pratama Jakarta Pluit minimal satu tahun. Penelitian ini menggunakan analisis jalur dengan sotfware SPSS dan Lisrel untuk pengolahan data. Berdasarkan hasil analisis, dapat diambil kesimpulan bahwa budaya organisasi berpengaruh secara langsung terhadap manajemen pengetahuan sebesar $10.89 \%$. Iklim organisasi berpengaruh secara langsung terhadap manajemen pengetahuan sebesar $6.40 \%$. Budaya organisasi berpengaruh secara langsung terhadap kompetensi sebesar 7.56\%. Iklim organisasi berpengaruh secara langsung kepadakompetensi sebesar $28.87 \%$ dan Manajemen pengetahuan berpengaruh secara langsung kepada kompetensi sebesar $9.80 \%$, sedangkan sisanya $90.20 \%$ dipengaruh factor lain. Budaya organisasi tidak terbukti dapat mempengaruhi kompetensi melalui manajemen pengetahuan secara tidak langsung. Iklim organisasi terbukti dapat mempengaruhi kompetensi melalui manajemen pengetahuan secara tidak langsung.
\end{abstract}

Kata kunci: Budaya Organisasi,I Ikliml Organisasi,l Manajemenl Pengetahuan,l Kompetensil Pegawai

\begin{abstract}
The aim of this research is to determine whether there is a direct and indirect significant effect of Organizational Culture, Organizational Climate, Knowledge Management, and Employee Competency. The population of this study are the employees of KPP Pratama Jakarta Tanjung Pluit from 11 sections, which are General section, Services, PDI, Intensification, Inspection, Billing, Supervision and Consultation 1-4, and Functional Examiner by 107 votes Civil Servants who served on KPP Pratama Jakarta Tanjung Pluit at least one year. This study uses statistical methods, namely the path analysis technique processed by the program SPSS and Lisrel, followed by structural equation modeling. Based on the analysis, the conclusions thus obtained are: Cultural organization directly affects knowledge management amounted to $10.89 \%$. Climate directly affects the organization of knowledge management at $6.40 \%$. The cultural organization directly affects the competence of $7.56 \%$. Climate organization directly affects the competence of $28.87 \%$ and knowledge management directly affect the competence of $9.80 \%$.
\end{abstract}

Keywords: Organizational Culture, Organizational Climate, Knowledge Management, Employee Competency

\section{Pendahuluan}

Perkembangan dunia usaha dan kondisi lingkungan yang dengan sangat cepat berubah serta tuntutan masyarakat yang terus meningkat, maka Direktorat Jenderal (Ditjen) Pajak terus mengupayakan perbaikan mekanisme kerja, sistem dan meningkatkan kinerja lembaga perpajakan. Hal ini juga didukung karena membludaknya pandangan negatif dari masyarakat umum, Wajib Pajak dan pengamat perpajakan kepada kurangnya kinerja pegawai Ditjen Pajak [1].

Oleh karena itu, Ditjen Pajak perlu terus melakukan perubahan ke arah yang lebih baik dan untuk itu Ditjen Pajak mencanangkan program reformasi perpajakan, dengan mendirikan Kantor Pelayanan Pajak berbasis administrasi modern. 
Program reformasi yang dicanangkan Ditjen Pajak bersifat komprehensif serta menyeluruh, mencakup perubahan teknologi, struktur organisasi, dan menerapkan manajemen Sumber daya manusia seperti peningkatan etika, moral, dan integritas dengan menerapkan fit and proper test, kode etik pegawai, mapping / pemetaan pegawai, peningkatan kebijakan perpajakokan, peningkatan pelayanan terhadap Wajib Pajak (WP) serta pengawasan terhadap pemenuhan kewajiban perpajakan WP dengan menggunakan sistem administrasi perpajakan modern serta ditunjang dengan teknologi informasi modern.

Adanya peralihan dan peningkatan ini diharapkan dapat memberikan kepuasan serta meningkatkan kinerja pegawai sehingga dapat memberikan pelayanan yang maksimal dan professional yang pada akhirnya diharapkan dapat memangkas jalur birokrasi menjadi lebih mudah dan cepat bagi masyarakat khususnya bagi wajib pajak saat melakukan hak dan kewajiban. Untuk menjamin tercapainya kinerja organisasi secara keseluruhan, dibutuhkan pegawai yang professional dan kompeten dibidangnya. Kemampuan dalam bentuk skill dan knowledge bisa didapat dari pendidikan dan pelatihan baik formal maupun informal, akses informasi dan pengalaman [2]. Namun kelemahan mendasar yang paling nyata adalah perubahan teknologi dan peraturan tidak diimbangi denganl peningkatanl pengetahuanl karenal minimnyal pelatihanl yangl diberikanl Direktoratl Jenderall Pajak, 1 padahal jika dibandingkan dengan perubahan yang terjadi sedemikian dinamis, pelatihan menjadi satu-satunya alat untuk menghilangkan gap antara kemampuan dengan tuntutan akibat perubahan yang terjadi, baik dari sisi budaya, teknologi, maupun regulasi [3].

Organisasi memerlukan manajemen pengetahuan (knowledge management) sebagai proses, yang meliputi membuat, menangkap, dan menerapkan pengetahuan untuk mencapai tujuan organisasi [4]. Knowledge management merupakan suatu kerangka yang digunakan untuk merancang sasaran organisasi, struktur, serta proses-prosesnya yang pada akhirnya organisasi dapat menciptakan suatu nilai baru untuk pelanggan dan komunitasnya [5].

Pegawai Direktorat Jenderal Pajak Jakarta Utara dalam menjalankan tugas belum sesuai dengan target kerja yang sudah ditetapkan oleh pimpinan dan masih harus meningkatkan kompetensinya. Hal ini terlihat juga penyelesaian wajib pajak hasil kerja belum memperhatian kualitas kerja hanya sekedar target kerja saja. Hal ini juga tidak terlepas dari inisiatif pegawai dalam penyelesaian wajib pajak dengan permasalahan yang hampir sama yaitu penunggakan pembayaran wajib pajak. Sebahagian pegawai sudah menggunakan teknologi dan masih ada yang belum maksimal menggunakan teknologi di dalam penyelesaian pekerjaan untuk wajib pajak. Pimpinan selalu menuntut pegawai membuat terobosan baru dalam peyelesaian wajib pajak dengan teknologi dan pegawai dapat berinovasi dalam bekerja.

Terlihat pada tabel di bawah bahwa dari tahun 2014-2018 target dan realisasi penerimaan pajak belum sesuai dengan target kerja yang sudah ditetapkan. Total target yang harus dicapai dari tahun 2009-2015 sebesar 6.612 namun realisasi hanya 5.786, sehingga rata-rata dari setiap tahun hanya mampu mencapai $87,5 \%$ saja dari target yang telah ditetapkan.

TABLE I

TARGET DAN REALISASI PENERIMAAN PAJAK

\begin{tabular}{|c|c|c|c|}
\hline Tahun & Target & Realisasi (Rp) & Realisasi (\%) \\
\hline 2014 & 1.072 triliun & 985 triliun & $91,9 \%$ \\
\hline 2015 & 1.294 triliun & 1.055 triliun & $81,5 \%$ \\
\hline 2016 & 1.539 triliun & 1.283 triliun & $83,4 \%$ \\
\hline 2017 & 1.283 triliun & 1.147 triliun & $89,4 \%$ \\
\hline 2018 & 1.424 triliun & 1.316 triliun & $92,4 \%$ \\
\hline Total & 6.612 triliun & 5.786 triliun & $87,5 \%$ \\
\hline
\end{tabular}

Sumber: Kementerian Keuangan, RAPBN 2019

Beberapa penelitian tentang kompetensi yang pernah dilakukan antara lain oleh [2, 6, 7, 8, 9]. Peningkatan kompetensi dibutuhkan dalam upaya mencapai tujuan organisasi. Perubahan serta pengembangan organisasi membutuhkan kompetensi yang harus dimiliki oleh setiap anggota organisasi. Kompetensi dapat memberikan dampak yang positif bagi pencapaian tujuan organisasi.

Penelitian empiris yang dilakukan oleh $[4,10,11$, 12, 13] mengenai manajemen pengetahuan menyatakan bahwa knowledge management berpengaruh signifikan terhadap kompetensi pegawai. Manajemen pengetahuan yang baik akan memperbaiki efektivitas dari suatu organisasi. Strategi yang dapat dilakukan ialah pengembangan berbagi pengetahuan dengan menghubungkan orang dengan orang serta dengan menghubungkan mereka pada suatu informasi sehingga mereka belajar dari pengalaman yang terabadikan.

Penelitian yang dilakukan oleh $[14,15,16]$ menunjukkan bahwa iklim organisasi yang nyaman dan menyenangkan bagi pegawai mempunyai pengaruh yang positif terhadap peningkatan performance pegawai karena iklim organisasi yang baik dapat mendorong organisasi memiliki sumber daya manusia yang berkompetensi, oleh sebab itu SDM memiliki peranan yang penting dalam organisasi dalam menciptakan berbagai macam inovasi dan merupakan komponen utama dan sebagai motor penggerak dalam setiap kegiatan. Demikian juga penelitian yang dilakukan oleh [17, 18, 19] yang menyatakan bahwa iklim organisasi yang mendukung, desentralisasi, terpadu akan mendukung manajemen pengetahuan.

Budaya organisasi adalah suatu realita dan kebiasaan-kebiasaan yang hidup dan dihayati oleh sebagian besar yang menjadi anggota organisasi. Penelitian mengenai budaya organisasi telah banyak dilakukan, antara lain oleh [14, 20]. Hasil penelitiannya menawarkan refleksi yang menarik, 
menggabungkan gagasan budaya dengan pengembangan kompetensi oleh individu. Dalam rangka mengembangkan kompetensi, orang harus mengakui nilai-nilai bersama perusahaan, mengingat bahwa mereka hanya masuk akal dalam konteks ini. Nilai tidak bisa dipaksakan dari atas ke bawah, tetapi harus muncul dari kelompok itu sendiri, kemudian pada tahap berikutnya, menjadi diformalkan.

Meskipun secara intensif sudah diteliti, namun hasil penelitian masih menunjukkan beberapa research gap, maka perlu dilakukan penelitian ulang untuk mengetahui faktor-faktor yang mempengaruhi kompetensi pegawai antara lain budaya organisasi, iklim organisasi, dan manajemen pengetahuan sebagai variabel moderasi.

Penelitian ini memiliki perbedaan mendasar dengan penelitian sebelumnya karena pada penelitian sebelumnya, tidak menggunakan variabel moderasi manajemen pengetahuan untuk memprediksi besarnya pengaruh terhadap kompetensi, selain itu penelitian ini dilakukan pada instansi pemerintah, sedangkan pada penelitian sebelumnya lebih fokus pada organisasi non publik/ non pemerintah. Berdasarkan permasalahan di atas, tujuan penelitian ini adalah untuk mengkaji pengaruh budaya organisasi, iklim organisasi, dan manajemen pengetahuan terhadap kompetensi pegawai Kantor Pelayanan Pajak Berbasis Administrasi Modern Di Lingkungan Kantor Pelayanan Pajak Pratama Jakarta Pluit baik secara langsung maupun tidak langsung.

\section{Kajian Pustaka}

\section{Kompetensi}

Menurut [21] kompetensi terdiri dari pengetahuan, keterampilan, sikap dan perilaku yang bersifat teknis, yang berkaitan dengan keterampilan pribadi dan berorientasi pada bisnis. Sedangkan menurut [6] kompetensi mencakup Karakteristik yang mendasari seseorang yang secara kausal terkait dengan kriteria yang dirujuk efektif dan kinerja unggul dalam suatu pekerjaan atau situasi).

Menurut [22] Kompetensi adalah karakteristik individu yang dapat diukur atau dihitung secara andal dan yang dapat ditunjukkan untuk membedakan secara signifikan antara pegawai yang berprestasi dan sedang-sedang, atau pegawai yang bekerja secara efektif dan tidak efektif. Selanjutnya Spencer and Spencer kompetensi adalah sikap dan perilaku, atau kemampuan dan kemauan dari seseorang yang relatif stabil saat menghadapi situasi dan kondisi di tempat kerja, yang terbentuk dari sinergi antara konsep diri, watak, motivasi internal, dan kapasitas pengetahuan konseptual.

[23] menyatakan bahwa kompetensi adalah deskripsi tentang perilaku, sementara kecakapan adalah hasil pekerjaan atau deskripsi tugas. Kompetensi mencakup pengetahuan, kemanpuan, kecerdasan, keterampilan seseorang sehingga dapat berperilaku kognitif, afektif, psikomotorik dengan hasil yang diharapkan. Kompetensi menurut [24] melihat kompetensi dari segi perbedaan individu yang dikaitkan dengan prestasi.
Kompetensi dapat didefinisikan sebagai kemampuan atau kemampuan [25]. Ini adalah satu set terkait tetapi berbeda dari perilaku yang diselenggarakan di bawah konstruk yang mendasari disebut 'niat' [25]. Selain itu, dapat dianggap sebagai kombinasi dari tacit dan eksplisit pengetahuan, sikap dan keterampilan yang mendorong individu untuk potensi efektivitas dalam kinerja tugas. Kompetensi dapat didefinisikan dalam hal kategori; definisi kompetensi; dan perilaku yang ditunjukkan [8].

Kompetensi adalah suatu kecakapan dalam melakukan suatu pekerjaan atau karakteristik yang dimiliki individu berkaitan dengan efektivitas dan efisiensi dalam melaksanakan pekerjaan. [7] menyatakan bahwa kompetensi sama dengan kemampuan, keterampilan, kecakapan, dan keahlian.

\section{Budaya Organisasi}

Menurut [14] memberikan definisi budaya organisasi sebagai pengetahuan sosial bersama dalam suatu organisasi mengenai aturan, norma, dan nilai-nilai yang membentuk sikap dan perilaku karyawannya. Dari pernyataan ini dapat dipahami, pertama, budaya disini adalah social knowledge di antara anggota organisasi. Kedua, budaya memberitahukan kepada karyawan tentang aturan, norma, dan nilai-nilai apa saja yang berlaku di dalam organisasi, Ketiga, budaya organisasi membentuk dan memperkuat sikap dan perilaku tertentu darikaryawan.

Menurut [26] budaya organisasi merupakan nilai bersama yang diyakini oleh para anggota organiasi, yang dapat mencirikan atau membedakan suatu organisasi dengan organisasi lainnya. Sistem makna bersama ini terdiri dari tujuh karateristik dasar yang merupakan esensi budaya organisasi, yaitu; inovasi dan pengambilan resiko, perhatian terhadap detail, orientasi hasil, orientasi orang, orientasi tim, keagresian, dan stabilitas. Selanjutnya [26] mengatakan bahwa manfaat budaya organisasi adalah dapat meningkatkan komitmen organisasi dan meningkatkan konsistensi perilaku karyawan.

[27] mengatakan budaya organisasi adalah dasar dari asumsi-asumsi dan nilai-nilai yang dianut bersama yang mengatur perilaku di dalam organisasi tertentu, yang mempunyai tiga fungsi utama; (1) sebagai bentuk control sosial yang melekat, (2) merupakan perekat social yang menyalurkan karyawan dan menjadikan mereka merasa sebagai bagian dari organisasi, dan (3) budaya membantu karyawan memahami tempat kerjanya. Budaya organisasi sebagai segala sesuatu tentang orang, berpikir, dan melakukan sebagai anggota masyarakat mereka. Ini adalah kriteria dasar perilaku sosial dan tindakan terpadu. Budaya organisasi mewakili karakter dari suatu organisasi, yang mengarahkan karyawan perilaku sehari-hari karyawan dalam bekerja dan panduan mereka tentang bagaimana bersikap dan berkomunikasi dalam organisasi, serta membimbing bagaimana hirarki perusahaan dibangun [15]. Budaya organisasi didefinisikan sebagai seperangkat nilai-nilai, 
keyakinan, asumsi, dan simbol yang dinyakini dalam organisasi.

Melihat budaya organisasi sebagai kombinasi kompleks sistem formal dan informal, proses, dan interaksi. Komponen budaya organisasi formal meliputi kepemimpinan, struktur, kebijakan, sistem reward, mekanisme sosialisasi, proses pengambilan keputusan, dan lainnya. Komponen budaya organisasi informal mencakup norma-norma implisit perilaku, nilai-nilai, panutan, mitos organisasi dan ritual, kepercayaan organisasi, sejarah anekdot, dan bahasa [10]. Selanjutnya Rai mengatakan budaya organisasi meliputi sesuatu yang dihargai, gaya kepemimpinan, simbol dan bahasa, prosedur dan rutinitas, serta keberhasilan suatu organisasi [10]. Menurut [28] budaya organisasi diterima hanya mengacu pada maksud bersama tentang kepercayaan dan pemahanan yang berpegang pada organisasi atau kelompok tertentu terkait dengan permasalahan, praktik, dan tujuan. Budaya organisasi pada terdiri dari : perilaku organisasi, filosofi organisasi dan ideologi, norma-norma yang berlaku pada organisasi, nilai-nilai yang diyakini organisasi, kebijakan dan procedur, serta aturan-aturan yang berlaku.

\section{Iklim Organisasi}

Iklim organisasi merupakan persepsi bersama antara karyawan mengenai kebijakan, praktik, peristiwa, dan prosedur formal dan informal dalam organisasi [12]. Selanjutnya [17], Iklim organisasi mengacu pada pengaruh lingkungan seperti lingkungan psikologis, lingkungan sosial, lingkungan organisasi dan situasional terhadap perilaku individu. Iklim kerja adalah apa yang dirasakan saat bekerja dalam suatu suatu kelompok, iklim kerja juga dapat disebut suasana kerja, menurut [20] menyatakan bahwaiklim kerja merupakan sifat kerja yang dinilai baik secara langsung ataupun secara tidak langsung oleh pegawai. Di dalam bekerja bahwa iklim kerja merupakan suasana yang terjadi dalam lingkungan kerja yang diciptakan oleh pola hubungan antara pribadi dalam bekerja.

Menurut [29], Iklim organisasi adalah kepribadian dari sebuah organisasi yang mencirikan satu organisasi dengan organisasi lainnya yang mengarah pada persepsi dari masing-masing anggota organisasi. Iklim organisasi tampak pada lingkungan kerja, selalu berusaha untuk menciptakan suasana kerja yang kondusif dan menciptakan hubungan yang harmonis sesama karyawan, sehingga akan memiliki semangat kerja untuk mencapai kualitas pelayanan kerja yang lebih baik. Selanjutnya [30], menyatakan bahwa iklim kerja ditentukan oleh hubungan sosial orang-orang yang ada dalam lingkungan pekerjaan, dan system kompensasi yang digunakan untuk memotivasi pegawai. Lebih jauh, Suprianto menyebutkan bahwa ada empat unsur utama yang berperan dalam pembentukan iklim kerja, meliputi; (1) decision making, (2) communication, (3) motivation, dan (4) attention to employees.

Iklim organisasi meruapakan persepsi bersama tentang apa yang organisasi lakukan, seperti dalam hal praktik, kebijakan, prosedur, rutinitas, dan rewardsapa yang penting dan apa perilaku yang diharapkan dan dihargai dan didasarkan pada persepsi bersama antara karyawan dalam unit-unit organisasi formal [19]. Iklim organisasi mengacu pada persepsi anggota ini dari lingkungan dan pengaruhnya pada organisasi formal dan informal, kepribadian individu, dan kepemimpinan organisasi. Dengan kata lain, ini adalah himpunan karakteristik internal organisasi yang mempengaruhi perilaku anggota mereka, mendorong mereka untuk bekerja aktif dan efektif, atau mungkin mendorong ketidakmampuan dan apatis terhadap pekerjaan dan organisasi di antara mereka [16].

Iklim organisasi adalah karakteristik yang relatif abadi dari suatu organisasi yang membedakannya dari organisasi lain, dan (a) mewujudkan persepsi kolektif anggota tentang organisasi mereka sehubungan dengan dimensi seperti kepercayaan, otonomi, kekompakan, pengakuan, dukungan, keadilan dan inovasi; (b) hasil dari interaksi anggota; (c) dasar untuk memprediksi situasi; (d) mencerminkan norma-norma umum, sikap budaya dan nilai organisasi, dan (e) dapat mempengaruhi perilaku [31].

Iklim organisasi merupakan hasil dari interaksi antara individu dalam suatu organisasi dengan lingkungan eksternalnya. Iklim organisasi merupakan seperangkat atribut yang dapat dirasakan dalam suatu organisasi, departemen atau unit. Selain itu, hasil iklim organisasi dari praktek rutin organisasi dan mempengaruhi sikap dan perilaku anggotanya [18].

\section{Manajemen Pengetahuan}

Secara umum manajemen pengetahuan dapat didefinisikan sebagai sebuah pengelolaan proses pengetahuan secara sistematis melalui pengetahuan baru yang diciptakan, diidentifikasi, dikelompokkan, dibagikan serta diaplikasikan. Pengetahuan yaitu proses manusiawi yang dinamis dalam melakukan pertimbangan dari keyakinan pribadi pada suatu kebenaran [5]. Selanjutnya manajemen pengetahuan (knowledge management) dianggap sebagai proses, yang meliputi membuat, menangkap, dan menerapkan pengetahuan untuk mencapai tujuan organisasi. Knowledge management adalah suatu kerangka untuk membangun sasaran organisasi, struktur, dan proses-prosesnya sehingga organisasi dapat menggunakan apa yang diketahuinya untuk belajar dan menciptakan suatu nilai baru untuk pelanggan dan komunitasnya [5].

Manajemen pengetahuan didefinisikan oleh [32] sebagai upaya untuk menghimpun pengetahuan secara sistematis, mengorganisasikannya, menyediakannya secara luas kepada seluruh organisasi, dan mengembangkan budaya belajar dan berbagai pengetahuan yang berkelanjutan. [13] memberikan definisi manajemen pengetahuan adalah strategi yang digunakan untuk mengelola pengetahuan organisasi sebagai aset dari perusahaan dan proses seperti penciptaan dan akuisisi, penyimpanan, berbagi dan diseminasi, 
pengambilan dan penggunaan pengetahuan tacit dan eksplisit. Ini tentang mengelola proses dan praktik yang bertindak berdasarkan pengetahuan tacit dan eksplisit. Praktek knowledge management merupakan serangkaian tindakan atau kegiatan yang terintegrasi dalam perilaku organisasi dan strategi yang mengembangkan dan mengoperasionalkan proses knowledge management. Nonaka dalam [33] mengatakan bahwa organisasi dengan rutinitas belajar akan menghasilkan kumpulan individu yang knowledgeable, baik explicit knowledge ataupun tacit knowledge.

Praktek knowledge management formal merupakan rangkaian upaya tindakan yang secara formal dirancang dan dilaksanakan (misalnya menghadiri konferensi dan pelatihan; membaca publikasi ilmiah, menciptakan dan menggunakan repositori yang tepat atau sistem teknologi, seperti database, arsip, manual, laporan berkala, standar operasional, laporan prosedur, internet, rapat kerja, bekerja sama dengan organisasi lain). Praktek knowledge management informal merupakan serangkaian kegiatan atau tindakan yang berlangsung tanpa desain formal, yaitu hasil dari jaringan informal yang dikembangkan dalam organisasi (misalnya berbagi cerita tentang peristiwa kerja masa lalu, berbagi pengalaman dan ide-ide, pertemuan informal dan percakapan tentang organisasi, solusi untuk tugas-tugas dan masalah kerja, dialog terbuka dan kritis dan refleksi tentang isu-isu organisasi dan kerja [13].

[5] mengembangan model terpadu penciptaan pengetahuan yang dinamis, pengetahuan digambarkan sebagai dinamis karena dibuat dalam interaksi sosial antara individu dan organisasi. Pengetahuan adalah spesifik konteks karena tergantung pada waktu tertentu dan ruang. Tanpa dimasukkan ke dalam konteks, itu hanyainformasi, bukan pengetahuan. Informasi menjadi pengetahuan ketika diinterpretasikan oleh individu dan diberikan konteks dan berlabuh di kepercayaan dan komitmenindividu [5].

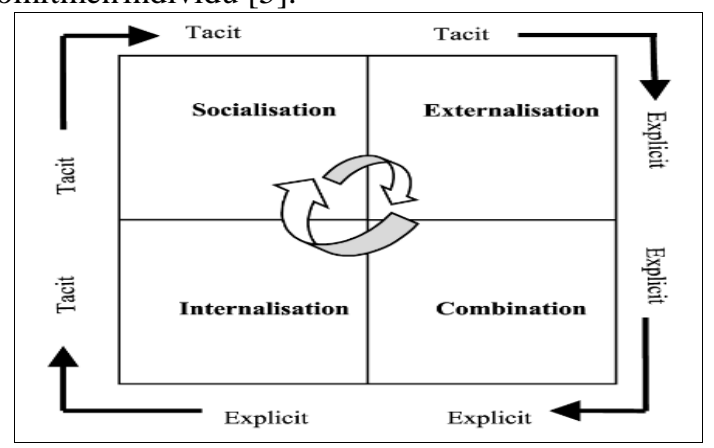

Gambar 1: SECI Proses

Kondisi dasar harus ada untuk evolusi pengetahuan dan penciptaan pengetahuan tacit. [5] mengembangkan model spiral pengetahuan: pengetahuan baru selalu dimulai dengan individu, misalnya seorang peneliti brilian memiliki wawasan yang mengarah ke paten baru, atau seorang pekerja toko lantai menarik pada tahun pengalaman untuk datang dengan inovasi proses. Dalam setiap kasus, pengetahuan pribadi seseorang berubah menjadi pengetahuan organisasi, yang mengembang melalui organisasi dan bernilai bagi perusahaan secara keseluruhan. Membuat pengetahuan pribadi tersedia untuk orang lain harus menjadi aktivitas utama dari pengetahuan dan inovasi menciptakan perusahaan. Ini terjadi terus menerus dan di semua tingkat organisasi. Melalui interaksi ini suatu organisasi membuat proses pengetahuan, yang disebut konversi pengetahuan.

[11] menggunakan empat dimensi pengukuran knowledge management yaitu: akuisisi pengetahuan, penciptaan pengetahuan, penyimpanan pengetahuan dan aplikasi pengetahuan.

\section{Metode Penelitian}

Penelitian ini mengambil lokasi di KPP Pratama Jakarta Pluit yang beralamat di Jl. Lodan No. 3, Ancol Jakarta. Penelitian dilaksanakan selama 6 (enam) bulan, mulai bulan Januari-Juni 2019.

Metode deskriptif dan metode korelasional digunakan dalam metode penelitian ini. Adapun populasinya adalah pegawai KPP Pratama Jakarta Tanjung Pluit yang tersebar 11 seksi yaitu seksi Umum, Pelayanan, PDI, Ekstensifikasi, Pemeriksaan, Penagihan, Pengawasan dan Kosultasi 1 - 4, dan Fungsional Pemeriksa. Karakreristik populasi adalah pegawai berstatus Pegawai Negeri Sipil yang bertugas di KPP Pratama Jakarta Pluit minimal satu tahun. Penelitian ini menggunakan sampel jenuh karena seluruh populasi dijadikan sampel penelitian. Jumlah populasi adalah sebesar 107 orang pegawai yang seluruhnya ditetapkan sebagai sampel penelitian.

Pengumpulan data dengan metode kuesioner, kemudian data jawaban responden dinilai skor dengan menggunakan Skala Likert. Proses pengolahan dan analisis data menggunakan software SPSS dan Lisrel, dengan tahapan sebagai berikut:

a. Uji Validitas.

b. Uji Reliabilitas

c. Uji Persyaratan Analisis

- Uji Normalitas

- Uji Multikolinearitas.

- Uji Heteroskedastisitas

- Uji Autokorelasi

d. Uji Hipotesis

Model penelitian yang terbentuk dapat digambarkan sebagai berikut: 


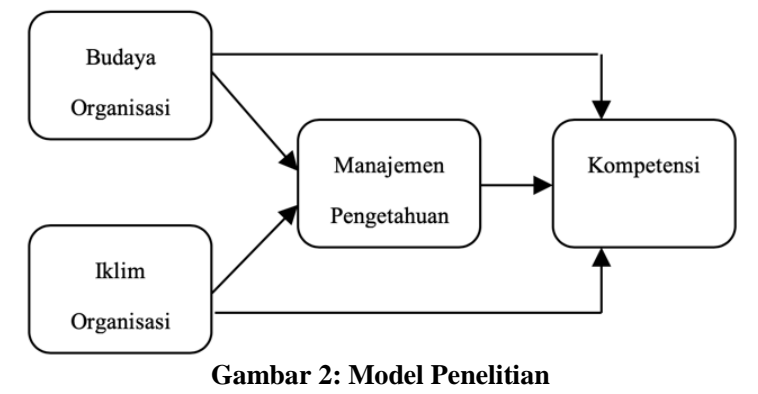

Sesuai model penelitian tersebut, maka rumusan hipotesis yang akan diuji adalah:

a. Diduga budaya organisasi berpengaruh terhadap manajemen pengetahuan secara langsung.

b. Diduga iklim organisasi berpengaruh terhadap manajemen pengetahuan secara langsung.

c. Diduga budaya organisasi berpengaruh terhadap kompetensi pegawai secara langsung.

d. Diduga iklim organisasi berpengaruh terhadap kompetensi pegawai secara langsung.

e. Diduga manajemen pengetahuan berpengaruh terhadap kompetensi pegawai secara langsung.

f. Diduga budaya organisasi berpengaruh terhadap kompetensi pegawai melalui manajemen pengetahuan secara tidak langsung.

g. Diduga iklim organisasi berpengaruh terhadap kompetensi pegawai melalui manajemen pengetahuan secara tidak langsung.

\section{Hasil dan Pembahasan}

Persamaan struktural yang diuji dalam model terdiri dari dua, yaitu persamaan manajemen pengetahuan dan kompetensi.

Manajemen pengetahuan:

$$
X_{3}=\beta X_{3} X_{1}+\beta X_{3} X_{2}+\epsilon_{1}
$$

Kompetensi:

$$
Y=\beta y X_{1}+\beta \mathrm{yX}_{2}+\beta \mathrm{yX}_{3}+\mathrm{C}_{2}
$$

Sifat analisis jalur yaitu untuk menganalisis hubungan kausal antar variabel yang digunakan dengan tujuan untuk mengetahui pengaruh langsung maupun tidak langsung, maka program yang memungkinkan untuk estimasi pengaruh langsung (direct effect) dan pengaruh tidak langsung (indirect effect) beserta uji signifikansi pengaruh tidak langsung adalah menggunakan program LISREL versi 8.80. Hasil persamaan struktural, tampilan output model disajikan dan dijelaskan secara berurutan berikut ini :

\section{TABLE 2}

EvALUASI GOODNESS OF FIT

Goodness of Fit Statistics
Degrees of Freedom $=0$
Minimum Fit Function Chi-Square $=0.0(\mathrm{P}=1.000)$
Normal Theory Weighted Least Squares Chi-Square $=0.00(\mathrm{P}=$
$1.000)$
The Model is Saturated, the Fit is Perfect!

Sumber: data lapangan, diolah dengan LISREL 8.80
Sebelum koefisien diinterpretasikan, maka pengujian pertama adalah melakukan evaluasi atas kecocokan model (goodness offit). Melalui tampilan di atas terlihat bahwa model fit sempurna dengan nilai degree of freedom 0 dan $\mathrm{p}$ value pada Chi-Square $=0$. Karena kecocokan model sudah sangat baik, maka pembahasan berikutnya yaitu menginterpretasikan persamaan struktural seperti tampilan sebagai berikut:

TABLE 3

\begin{tabular}{|c|c|c|c|}
\hline \multicolumn{4}{|c|}{ Structural Equations } \\
\hline \multicolumn{4}{|c|}{$X 3=0.276 * X_{1}+0.400 * X_{2}$, Errorvar. $=31.764, R^{2}=0.570$} \\
\hline$(0.110)$ & $(0.0814)$ & \multicolumn{2}{|c|}{$(5.369)$} \\
\hline 2.513 & 4.908 & \multicolumn{2}{|c|}{5.916} \\
\hline \multirow{2}{*}{\multicolumn{4}{|c|}{$\begin{array}{l}\mathrm{Y}=+0.358 * \mathrm{X}_{1}+0.204 * \mathrm{X}_{2}+0.338 * \mathrm{X}_{3}, \text { Errorvar }=31.207 \\
\mathrm{R}^{2}=0.638\end{array}$}} \\
\hline & & & \\
\hline$(0.114)$ & $(0.0936)$ & $(0.118)$ & $(5.275)$ \\
\hline 3.150 & 2.176 & 2.852 & 5.916 \\
\hline
\end{tabular}

PERSAMAAN STRUKTURAL

Sumber: data lapangan, diolah dengan LISREL 8.80

\begin{tabular}{|c|c|}
\hline \multicolumn{2}{|c|}{ PENGARUH TOTAL DAN TIDAK LANGSUNG } \\
\hline \multicolumn{2}{|c|}{ Total and Indirect Effects } \\
\hline \multicolumn{2}{|c|}{ Total Effects of X on Y } \\
\hline $\mathrm{x} 1$ & $\mathrm{x} 2$ \\
\hline $\begin{array}{c}0.276 \\
(0.110) \\
2.513\end{array}$ & $\begin{array}{l}0.400 \\
(0.081) \\
4.908\end{array}$ \\
\hline $\mathrm{Y} \begin{array}{c}0.451 \\
(0.115) \\
3.924\end{array}$ & $\begin{array}{l}0.339 \\
(0.085) \\
3.972\end{array}$ \\
\hline \multicolumn{2}{|c|}{ Indirect Effects of $\mathrm{X}$ on $\mathrm{Y}$} \\
\hline $\mathrm{x} 1$ & $\mathrm{x} 2$ \\
\hline $\mathrm{x} 3$ & - \\
\hline Y $\begin{array}{c}0.093 \\
(0.049) \\
1.885\end{array}$ & $\begin{array}{l}0.135 \\
(0.055) \\
2.466\end{array}$ \\
\hline
\end{tabular}

TABLE 4

Parameter uji hipotesis menggunakan perbandingan nilai $\mathrm{t}$, yaitu jika nilai $\mathrm{t}$ hitung $>$ dari $\mathrm{t}$ table $(\mathrm{t}$ kritis $=$ 1.96), maka $\mathrm{H}_{0}$ ditolak dan $\mathrm{H}_{\mathrm{a}}$ diterima.

\section{Permbahasan}

1) Budaya organisasi berpengaruh terhadap manajemen pengetahuan pegawai KPP Pratama Jakarta Pluit.

Koefisien jalur budaya organisasi terhadap manajemen pengetahuan memiliki nilai koefisien unstandard sebesar 0.276 dan t hitung sebesar 2.513. Nilai tersebut diperoleh memenuhi syarat untuk penerimaan $\mathrm{H}_{1}$ yaitu nilai thitung yang lebih besar dari 1,96. Hasil dari penelitian ini dapat disimpulkan bahwa budaya organisasi terbukti dapat mempengaruhi manajemen pengetahuan secara positif dan langsung pada pegawai KPP Pratama Jakarta Pluit. Dapat dikatakan pula bahwa semakin baik budaya organisasi, maka akan berimplikasi pada semakin tingginya manajemen pengetahuan pegawai KPP Pratama 
Jakarta Pluit.

Hasil penelitian ini selaras dengan penelitian yang dilakukan [15] bahwa budaya organisasi merupakan pendorong penting di balik semua gerakan dalam organisasi melalui perilaku-perilaku individunya. Dampak budaya organisasi ada pertukaran pengetahuan, interaksi mengkombinasikan, dan nilai yang dirasakan dari anggota organisasi sehingga memiliki dampak yang signifikan terhadap kemampuan penciptaan pengetahuan. Dalam konteks manajemen pengetahuan, pembudayaan nilai-nilai yang mendukung knowledge management harus dilakukan secara efektif. Dengan demikian, komitmen pimpinan dalam menanamkan budaya organisasi yang mendukung knowledge management sangat berperan besar. Penelitian yang mendukung hasil penelitian ini ialah penelitian yang dikerjakan oleh [10] yang menemukan bahwa budaya organisasi sangat penting dalam menciptakan pengetahuan dan bagaimana aspek budaya organisasi seperti kolektivisme memiliki dampak positif pada manajemen pengetahuan.

KPP Pratama Jakarta Pluit telah berusaha memberikan pelayanan yang terbaik kepada para stakeholder demi terwujudnya good governance dengan menciptakan budaya organisasi dan budaya kerja yang selaras dengan nilai-nilai Kementerian Keuangan. Nilai-nilai budaya organisasi tersebut harus menjadi suatu nyawa menjadi bagian sistem kerja KPP Pratama Jakarta Pluit yang tak terpisahkan.

Implikasi yang bisa dilakukan oleh pimpinan KPP Pratama Jakarta Pluit adalah dengan membangun budaya pengetahuan (knowledge sharing culture) yang yang dilakukan secara terus menerus, serta konsisten. Knowledge sharing culture dapat meningkatkan kreativitas dan pengetahuan serta inovasi sehingga pegawai KPP Pratama Jakarta Pluit dapat lebih meningkatkan performa dan kinerjanya.

Sikap yang harus ditumbuh kembangkan dan dibudayakan oleh para pegawai KPP Pratama Jakarta Pluit dalam pembentukan manajemen pengetahuan ini diantaranya dorongan kuat untuk; menciptakan, menangkap, menjaring, menyimpan, mengolah, dan menyebarluaskan knowledge yang dimiliki kepada pegawailain.

\section{2) Iklim organisasi berpengaruh terhadap manajemen pengetahuan pegawai KPP Pratama Jakarta Pluit.}

Koefisien jalur iklim organisasi terhadap manajemen pengetahuan memiliki nilai koefisien unstandard sebesar 0.400 dan thitung sebesar 4.908. Nilai tersebut memenuhi syarat untuk penerimaan $\mathrm{H}_{2}$ yaitu nilai t hitung yang lebih besar dari 1,96. Hasil penelitian ini menyimpulkan bahwa iklim organisasi terbukti dapat mempengaruhi manajemen pengetahuan secara positifdanlangsung pada pegawai KPP Pratama Jakarta Pluit. Semakin baikiklim organisasi, maka akan berimplikasi pada semakin tingginya manajemen pengetahuan pegawai KPP Pratama Jakarta Pluit.
[15] menemukan bahwa iklim etika dalam organisasi dan kemungkinan pengaruh terhadap evaluasi anggota, kepuasan, keterlibatan, dan prestasi kerja sehubungan dengan praktek manajemen pengetahuan. Hasil penelitian ini mengungkapkan bahwa beberapa jenis organisasi memiliki derajat yang berbeda, dan berpengaruh terhadap sikap karyawan serta partisipasi dalam kegiatan manajemen pengetahuan. Dalam penelitiannya, [15] menyimpulkan pentingnya iklim organisasi dan menyoroti implikasi iklim untuk memfasilitasi manajemen pengetahuan.

Iklim organisasi yang mendukung akan membantu mempromosikan representasi bersama, interpretasi, dan sistem makna antara orang-orang dan karena itu akan meningkatkan kerja sama tim melalui penciptaan suasana kerja sama dan keterbukaan. Iklim organisasi yang mendukung dapat dianggap sebagai kekuatan yang bersama-sama dan memungkinkan para pegawai berbagi dan menyumbangkan pengetahuan mereka untuk membantu mencapai tujuan bersama. Ketika pegawai KPP Pratama Jakarta Pluit merasa iklim organisasi yang mendukung, mereka akan lebih mungkin untuk secara terbuka bertukar informasi, bekerja sama secara kolektif, dan mencoba pendekatan baru untuk pekerjaan mereka.

Implikasi penelitian ini, upaya yang harus dilakukan oleh pimpinan KPP Pratama Jakarta Pluit adalah menciptakan iklim organisasi yang terbuka, karena dengan iklim organisasi yang terbuka maka semangat kerja pegawai akan tinggi, motivasi atasan kepada bawahan agar lebih berprestasi, pegawai dapat dengan bebas berbagi (sharing) pengetahuan satu sama lain sehingga dapat menciptakan efektifnya manajemen pengetahuan. Sebaliknya, bila iklim organisasi tertutup, maka semangat kerja karyawan akan rendah, dorongan pimpinan untuk memotivasi karyawan berprestasi akan rendah, yang pada akhirnya menyebabkan pegawai enggan untuk saling berbagi pengetahuan.

\section{3) Budaya organisasi berpengaruh terhadap kompetensi pegawai KPPPratama Jakarta Pluit.}

Koefisien korelasi jalur budaya organisasi terhadap kompetensi mempunyai nilai koefisien unstandard sebesar 0.358 dan thitung sebesar 3.150. Nilai tersebut memenuhi syarat untuk penerimaan $\mathrm{H}_{3}$ yaitu nilai t hitung yang lebih besar dari 1,96. Hasil penelitian ini dapat disimpulkan bahwa budaya organisasi terbukti dapat mempengaruhi kompetensi secara positif dan langsung pada pegawai KPPPratama Jakarta Pluit. Semakin baik budaya organisasi, maka akan berimplikasi pada semakin tingginya kompetensi pegawai KPPPratama Jakarta Pluit.

Dalam mengembangkan kompetensi, orang harus mengakui nilai-nilai bersama perusahaan, mengingat bahwa mereka hanya masuk akal dalam konteks ini. Nilai tidak bisa dipaksakan dari atas ke bawah, tetapi harus muncul dari kelompok itu sendiri, kemudian 
pada tahap berikutnya, menjadi diformalkan. Meskipun ada perbedaan yang signifikan dalam hal persepsi antara berbagai tingkat perusahaan, perbedaan sosial tertentu dan kepentingan yang berbeda, dalam lingkungan profesional, budaya dapat dibagi, sehingga membentuk sebuah bahasa yang sama tentang apa yang akan praktek yang kompeten dalam skenario profesional tertentu.

Implikasi yang bisa dilakukan oleh pimpinan KPP Pratama Jakarta Pluit adalah memperbaiki budaya organisasinya misalnya dengan cepat memberikan respon atas semua pergantian yang terjadi, meningkatkan kerjasama tim dan berusaha untuk mencapai target penerimaan pajak, serta lebih memberikan tempat kepada pegawai untuk berkreativitas dalam menciptakan gagasan baru dalam melaksanakan pekerjaannya. Selain itu pimpinan KPP Pratama Jakarta Pluit juga harus mampu menciptakan situasi kerja yang memotivasi pegawai dan mampu mendorong pegawai untuk meningkatkan kompetensi.

\section{4) Iklim organisasi berpengaruh terhadap kompetensi pegawai KPP Pratama Jakarta Pluit.}

Koefisien jalur iklim organisasi terhadap kompetensi memiliki nilai koefisien unstandard sebesar 0.204 dan $t$ hitung sebesar 2.176. Nilai tersebut memenuhi syarat untuk penerimaan $\mathrm{H}_{4}$ yaitu nilai $\mathrm{t}$ hitung yang lebih besar dari 1,96. Hasil penelitian ini dapat disimpulkan bahwa iklim organisasi terbukti dapat mempengaruhi kompetensi secara positif dan langsung pada pegawai KPP Pratama Jakarta Pluit. Semakin baik iklim organisasi, maka akan berimplikasi pada semakin tingginya kompetensi pegawai KPP Pratama Jakarta Pluit.

Kompetensi yang diharapkan dari pegawai KPP Pratama Jakarta Pluit adalah: 1) seorang pegawai diharapkan mempunyai jiwa professional dan kompeten dalam menjalankan tugas di bidangnya masing-masing untuk memberikan pelayanan terhadap Wajib Pajak. 2) Adanya pengukuran Nilai Kerja Pegawai di setiap semester sehingga pegawai dituntut bekerja sesuai program kerja yang telah ditetapkan. Untuk mencapai kompetensi yang diharapkan tersebut maka diperlukan iklim organisasi yang terbuka yang memperlakukan pegawai secara adil dan menyenangkan serta adanya kesungguhan pimpinan KPP Pratama Jakarta Pluit untuk mengelola sumber daya manusia yang dimilikinya dengan maksimal.

\section{5) Manajemen pengetahuan berpengaruh terhadap kompetensi pegawai di KPP Pratama Jakarta Pluit.}

Koefisien jalur pengaruh manajemen pengetahuan terhadap kompetensi memiliki nilai koefisien unstandard senilai 0.338 serta t hitung senilai 2.852 . Nilai tersebut diperoleh melalui pemenuhan syarat untuk penerimaan $\mathrm{H}_{5}$ yaitu nilai thitung yang lebih besar dari 1,96. Jadi dapat diambil kesimpulan bahwa manajemen pengetahuan terbukti dapat mempengaruhi kompetensi secara positif dan langsung pada pegawai KPPPratama Jakarta Pluit. Dengan demikian, semakin baik manajemen pengetahuan, maka akan berimplikasi pada semakin tingginya kompetensi pegawai KPP Pratama JakartaPluit.

Penciptaan pengetahuan dicapai dengan menciptakan lingkungan yang mendukung, melalui SDM yang diperlukan, untuk individu, kelompok dan tim untuk ditantang oleh permasalahan organisasi, untuk mencari solusi masalah dan berinovasi dimulai dari penciptaan posisi dan tim, untuk penyediaan umpan balik arus informasi, dengan desain remunerasi merangsang dan sistem lain sebagai dorongan. Ini termasuk juga investasi dalam pelatihan dan pengembangan sumber daya manusia. Transfer pengetahuan menyangkut berbagai bentuk pembelajaran, penciptaan pengetahuan berbagi iklim, pembentukan unit pelatihan yang menilai dan menganalisa kebutuhan pelatihan, menyediakan dan mengevaluasi pelatihan, dan memimpin menuju organisasi belajar. Akhirnya, dengan tingginya manajemen pengetahuan maka kompetensi pegawai pun akan meningkat.

Untuk meningkatkan kompetensi bisa dengan cara belajar melalui pendidikan yang merupakan proses pengembangan SDM. Beberapa upaya yang dilakukan untuk mengembangkan knowlegde management KPP Pratama Jakarta Pluit antara lain:

a) Pendidikan dan latihan (diklat) yang selalu diadakan untuk menunjang kompetensi pegawai yang diadakan di pusdiklat Pajak, antara lain diklat account representative, diklat fungsional pemeriksa pajak, diklat pelatihan teknis komputer dan programming, diklat Juru sita, diklat penggalian potensi dan lain - lain yang semuanya untuk menunjang dalam proses pelaksanaan tugas dikantor.

b) Program Beasiswa untuk melanjutkan pendidikan, antara lain: Program beasiswa untuk jenjang strata 1 di perguruan Tinggi Negeri, Program beasiswa untuk jenjang strata 2/ Magister baik dalam negeri ataupun luar negeri dan Program beasiswa untuk jenjang S3.

c) Seminar dan sosialisasi tentang peraturan-peraturan perpajakan atau dunia bisnis sehingga petugas pajak selalu mendapatkan pengetahuan seiring perkembangan teknologi dan dunia usaha.

d) Simtim jaringan computer yang terintegrasi sehingga pegawai pajak dapat dengan mudah mengakses segala peraturan dan informasi perpajakan yang dikenal dengan Sistim Informasi Direktorat Jenderal Pajak (SIDJP).

6) Budaya organisasi berpengaruh terhadap kompetensi pegawai KPP Pratama Jakarta Pluit melalui manajemen pengetahuan secara tidak langsung.

Koefisien korelasi jalur budaya organisasi 
terhadap kompetensi mempunyai nilai koefisien unstandard senilai 0.093 dan thitung senilai 1.885. Nilai tersebut tidak mampu memenuhi syarat untuk penerimaan $\mathrm{H}_{6}$ yaitu nilai t hitung lebih kecil dari 1,96. Jadi dapat disimpulkan bahwa budaya organisasi tidak terbukti dapat mempengaruhi kompetensi melalui manajemen pengetahuan secara tidak langsung pada pegawai KPPPratama Jakarta Pluit.

Strategi MSDM yang berbasis kompetensi perlu didukung oleh budaya organisasi yang tepat. Budaya organisasi yang kuat dan relevan mengarahkan tingkah laku pegawainya pada satu cara untuk mencapai sasaran organisasi yang pada akhirnya akan meningkatkan kompetensi.

Upaya untuk meningkatkan kompetensi salah satunya bisa dengan pendidikan karena dengan pendidikan merupakan proses pengembangan diri pegawai, peagawai akan belajar mandiri dan kemampuan dasar yang ada pada dirinya akan berkembang. Pendidikan akan membawa perubahan pada tingkah laku manusia, baik dalam cara berpikirnya, pengetahuan, serta sikap mentalnya.

7) Iklim organisasi berpengaruh terhadap kompetensi pegawai KPP Pratama Jakarta Pluit melalui manajemen pengetahuan secara tidak langsung.

Koefisien jalur iklim organisasi terhadap kompetensi memiliki nilai koefisien unstandard senilai 0.135 dan $\mathrm{t}$ hitung sebesar 2.466. Nilai tersebut memenuhi syarat dalam penerimaan $\mathrm{H}_{7}$ yaitu nilai $\mathrm{t}$ hitung yang lebih besar dari 1,96. Jadi dapat disimpulkan bahwa iklim organisasi terbukti dapat mempengaruhi kompetensi melalui manajemen pengetahuan secara tidak langsung pada pegawai KPP Pratama Jakarta Pluit.

Implikasi yang bisa dilakukan oleh pimpinan KPP Pratama Jakarta Pluit untuk meningkatkan iklim organisasi adalah menciptakan iklim organisasi yang mendukung perbaikan didalam berbagai aspek, mampu membangun koordinasi yang baik antar fungsi di dalam suatu organisasi, dan terlibat penuh dalam menciptakan iklim organisasi yang kondusif untuk meningkatkan kompetensi pegawai KPP Pratama Jakarta Pluit. Agar pegawai KPP Pratama Jakarta Pluit dapat bekerja secara optimal serta memiliki loyalitas yang tinggi, maka KPP Pratama Jakarta Pluit harus bisa menciptakan iklim organisasi yang baik serta menyenangkan, sehingga pegawai yang sudah terbentuk memiliki manajemen pengetahuan yang tinggi yang pada akhirnya terbentuklah pegawai KPP Pratama Jakarta Pluit yang memiliki kompetensi yang mumpuni.

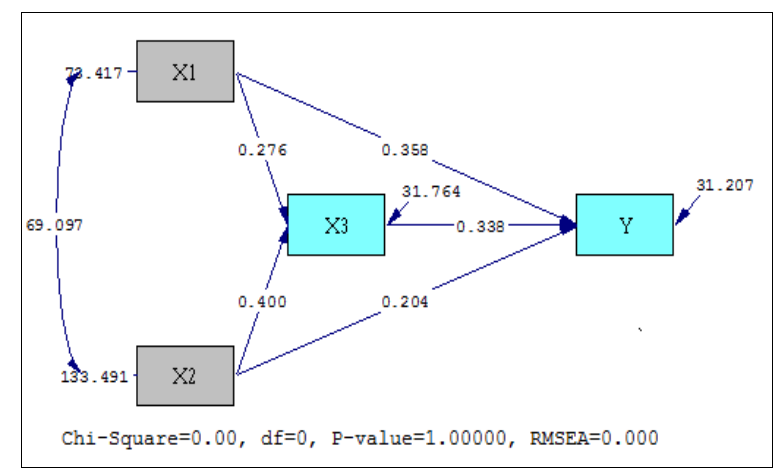

Gambar 3: Diagram Jalur Hubungan (Unstandardized)

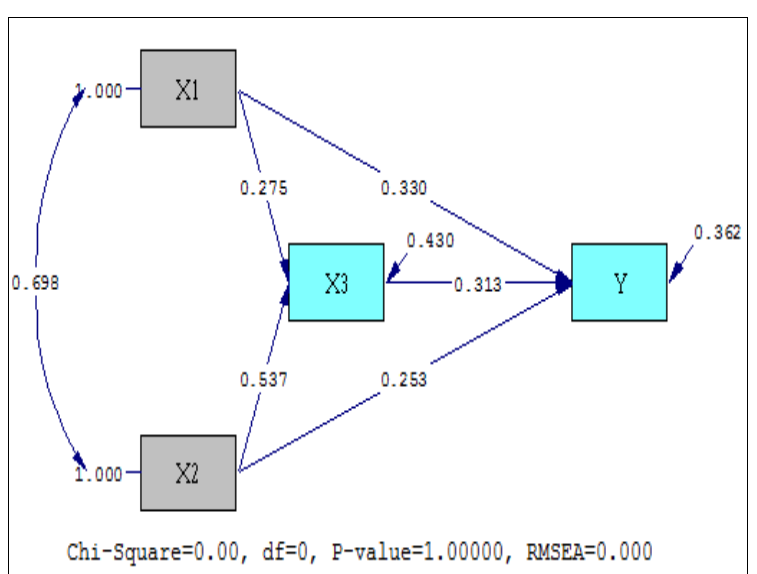

Gambar 4: Diagram Jalur Hubungan (Standardized)

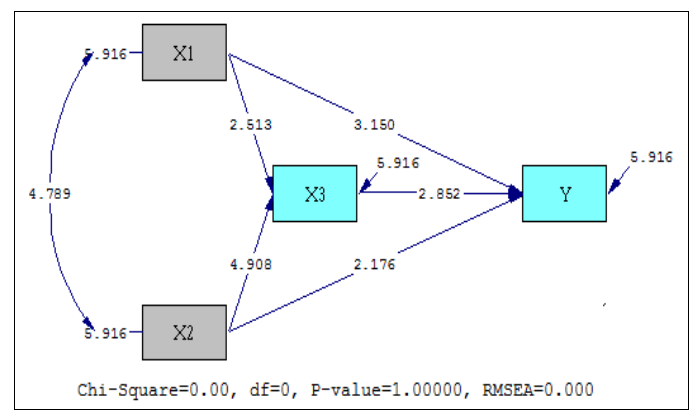

Gambar 5: Uji t Model Struktural

Untuk membandingkan mana koefisien yang paling dominan dalam mempengaruhi kompetensi, maka nilai koefisien standard lebih direkomendasikan. Melalui koefisien standar terlihat bahwa pada struktur pertama yaitu dengan menempatkan manajemen pengetahuan sebagai variabel endogen terlihat bahwa iklim organisasi merupakan faktor dominan dalam mempengaruhi manajemen pengetahuan dengan koefisien standar sebesar 0.537, sedangkan budaya organisasi adalah sebesar 0.275 . Pada struktural kedua diketahui bahwa budaya organisasi merupakan aspek dominan dalam mempengaruhi kompetensi dengan koefisien standar sebesar 0.330 , disusul manajemen pengetahuan (0.313), dan terakhir adalah aspek iklim organisasi (0.253). 


\section{Kesimpulan}

Jadi berdasarkan hasil analisis diatas, maka beberapa kesimpulan yang bisa didapat antara lain: budaya organisasi berpengaruh secara langsung kepada manajemen pengetahuan. Iklim organisasi berpengaruh secara langsung terhadap manajemen pengetahuan. Budaya organisasi berpengaruh secara langsung terhadap kompetensi. Iklim organisasi berpengaruh secara langsung terhadap kompetensi. Manajemen pengetahuan berpengaruh secara langsung terhadap kompetensi. Budaya organisasi tidak terbukti dapat mempengaruhi kompetensi melalui manajemen pengetahuan secara tidak langsung. Iklim organisasi terbukti dapat mempengaruhi kompetensi melalui manajemen pengetahuan secara tidak langsung.

\section{Daftar Pustaka}

A. Hadini, A. U., Lituhayu, D., \& Lestari, H. (2012). Perubahan Sistem Organisasi Perpajakan di Direktorat Jenderal Pajak Studi Kasus Kantor Pelayanan Pajak Pratama Semarang Gayamsari. Journal of Public Policy and Management Review, Vol. 1 No. 1. pp. 41-50.

B. Handayani, A. (2015). Pengaruh Kemampuan, Kecakapan Dan Keterampilan Terhadap Kinerja Auditor di Kota Metro. e-JKPP, Vo. 1 No. 1.pp. 34 $-46$

C. Kompas.com, 8 Juni 2016 yang diakses pada tanggal 27 Mei 2018.

D. Anshori, Y. (2005). Analisis keunggulan bersaing melalui penerapan knowledge management dan knowledge-based strategy di Surabaya Plaza Hotel. Jurnal Manajemen Perhotelan, Vol. 1 No. 2. pp. $45-57$.

E. Budiharjo, Andreas, (2011), Organisasi : Menuju Pencapaian Kinerja Optimum. Prasetya Mulya Publishing, Jakarta.

F. De Vos, A., De Hauw, S., \& Van der Heijden, B. I. (2011). Competency development and career success: The mediating role of employability. Journal of vocational behavior, Vol. 79, No. 2, pp. 438-447.

G. Janjua, Saquib Yusaf, Naeem, Malik Asghar; Kayani, Farrukh Nawaz, 2012, The Competence Classification Framework A Classification Model For Employee Development, Interdisciplinary Journal of Contemporary Research In Business, Vol. 4. No.1 pp. 396-404.

H. Setyaningdyah, Endang; Nimran, Kertahadi Umar; Thoyib, Armanu, (2013), The Effects of Human Resource Competence, Organisational Commitment and Transactional Leadership on Work Discipline, Job Satisfaction and Employee's
Performance, Interdisciplinary Journal of Contemporary Research In Business, Vol .5. No.4, pp. 140-153.

I. Pangestuti, D. C. (2019). Analisis Pengalaman Kerja, Kompetensi, Pendidikan Dan Pelatihan Terhadap Pengembangan Karir Dengan Intervening Prestasi Kerja. Jurnal Riset Manajemen dan Bisnis (JRMB) Fakultas Ekonomi UNIAT, 4(1), 57-68.

J. Rai, Rajnish Kumar, (2011), Knowledge Management and Organizational Culture: A Theoretical Integrative Framework, Journal of Knowledge Management, Vol. 15. No.5, pp.779-801

K. Aujirapongpan, S., Pakpachong Vadhanasindhu, Achara Chandrachai, Pracob Cooparat, (2012) "Indicators of Knowledge Management Capability for KM Effectiveness", VINE, Vol. 40 Iss: 2, pp.183 $-203$

L. Boh, Wai Fong; Wong, Sze Sze. (2013) Organizational Climate and Perceived Manager Effectiveness: Influencing Perceived Usefulness of Knowledge Sharing Mechanisms. Journal of the Association for Information Systems Vol14. No..3, pp.122-152.

M. Cardoso, Leonor; Meireles, Andreia; Carlos Ferreira Peralta. (2012), Knowledge Management and Its Critical Factors in Social Economy Organizations, Journal of Knowledge Management Vol. 16. No. 2, pp. 267-284.

N. Colquit, Jazon A, Jeffery A, Lepine, and Michael J Wesson, (2009), Organizatonal Behavior; Improving Performance and Commitment in the Worksplace, Mcgraw-Hill International, Edition, Boston.

O. Tseng, Fan-chuan; Fan, Yen-Jung. (2011), Exploring the Influence of Organizational Ethical Climate on Knowledge Management, Journal of Business Ethics, Vol. 01.No. 2. pp. 325-342

P. Darabi, Salman; Neyestani, Mohamadreza; Ghafari, Mohamad; Maidanipour, Katayoon; Mard, Seyedmohammad. (2013), Studying Relationship between Organizational Climate and Developing Entrepreneurial Spirit among Postgraduate Students (The Case of University of Isfahan). Journal of Sociological Research, Vol. 4. No.1 pp. 172-184.

Q. Fenwick, Feng Jing; Avery, Gayle C; Bergsteiner, (2011), Harald, Organizational Climate and Performance in Retail Pharmacies, Leadership \& Organization Development Journal Vol.32. No.3, pp. 224-242.

R. Zakari, Nazik M A. (2012), The Influence of Academic Organizational Climate on Nursing

103 | Jurnal Akuntansi, Ekonomi dan Manajemen Bisnis | Vol. 8 No.1, July 2020, 94-104 | E-ISSN: 2548-9836 
Faculty Members' Commitment in Saudi Arabia, Journal of Higher Education Theory and Practice, Vol. 12. No1. pp. 66-76.

S. Permarupan, P Yukthamarani; Al-Mamun, Abdullah; Saufi, Roselina Ahmad; Zainol, Noor Raihani Binti, (2013), Organizational Climate on Employees' Work Passion: A Review. Canadian Social Science Vol. 9.No. 4, pp. 63-68.

T. Gibson, Ivancevich, dan Donelly, (2009), Organization Behavior, Structure, Process, New York; Mc Garw, Hill.

U. Mondy, R. Wayne., (2008), Manajemen Sumber Daya Manusia, Penerbit Erlangga, Jakarta.

V. Vichita, Vathanophas, (2007). Business process approach towards an inter-organizational enterprise system. Business Process Management Journal, 13(3), pp. 433-450.

W. Palan, R. (2013), Competence Management-A Practicionser's Guide (Competency Management, Teknik Mengimplementasikan Manajemen SDM Berbasis Kompetensi untuk Meningkatkan Daya Saing Organisasi), PPM, Jakarta.

X. Pangestuti, D. C. (2018). Faktor-Faktor Yang Mempengaruhi Kompetensi Pramuwisata. Jurnal Manajemen, 10(2), 120-128.

Y. Boyatzis, R. E. (2009), The Competent Manager. A Model for Effective Performance. Jhon Wiley \& Sons. USA.

Z. Robbin, Stephen P dan Timothy Judge, (2009), Organizational Behavior, Prentice Hall, New Jersey.

AA. McShane, Steven L. and Mary Ann Von Glinow, (2009), Organizational Behavior, Fourth edition, McGraw-Hill Irwin, New York.

BB. Kropp, Richard, 2014, The Importance Of Organizational Culture, (http;www.amsconsulting.comAR, Torgculture.Com.html).

CC. Newstrom, Jhon W and Davis, Keith, (2010), Organizational Behavior, Human Behavior at Work, The McGraw-Hill, Company, New York.

DD. Suprianto, Jhon, (2013), Penilaian Pendidikan Kompetensi Dan Prateknya, Bumi Aksara, Jakarta,

EE. Irzani, D. (2014), Pengaruh Konflik Peran dan Ambiguitas Peran terhadap Keinginan Keluar Karyawan dengan Kepuasan Kerja sebagai Variabel Mediasi pada PT. Asuransi Raksa Pratikara di Surabaya. Jurnal Ilmu Manajemen (JIM), 2(1). pp.103-121

FF.Daft., Richard L., (2010), Era Baru Manajemen.

104 | Jurnal Akuntansi, Ekonomi dan Manajemen Bisnis | Vol. 8 No.1, July 2020, 94-104 | E-ISSN: 2548-9836
Salemba Empat, Jakarta.

GG. Rengkung, L. R., Pangemanan, L. R., \& Lorraine, W. Pengaruh Tacit Knowledge terhadap Inovasi Produk pada Industri Kreatif Kerajinan di Kabupaten Minahasa, Sulawesi Utara. MIX: Jurnal Ilmiah Manajemen, Vol. 9, No. 1, pp. 160-173 